\title{
Weekly Cetuximab and Gemcitabine plus Cisplatin as Salvage Therapy for Unresectable Non-Small Cell Lung Cancer
}

\author{
Cheng-Jeng Tai ${ }^{a, b}$ Chung-Huei Hsu ${ }^{c}$ Feng-Jeh Wang ${ }^{d}$ Wing-Keung Chau ${ }^{a}$ Chi-Li Chung \\ Chih-Cheng Hsieh ${ }^{e, f}$
}

a Section of Hematology-Oncology, Taipei Medical University Hospital,

${ }^{b}$ School of Medicine, Taipei Medical University,

${ }^{\mathrm{C}}$ Department of Nuclear Medicine,

${ }^{d}$ Section of Chest, Department of Medicine, Taipei Medical University Hospital,

${ }^{e}$ Department of Thoracic Surgery, Taipei Veterans General Hospital,

${ }^{\dagger}$ School of Medicine, National Yang-Ming University, Taipei, Taiwan

\begin{abstract}
A 44-year-old man had a persistent cough and lost more than $5 \mathrm{~kg}$ within 2 months before April 2007. He was found to have a 5-cm mass around the left middle lung field, and underwent a computed tomography-guided biopsy which showed primary non-small cell lung cancer (NSCLC). Clinical staging was as T3NxM0. The patient underwent concurrent chemotherapy with regular-dose docetaxel plus cisplatin, and radiotherapy at a local hospital. Tumor growth persisted, and in August 2007 the tumor almost obstructed the left main bronchus. Thus, he was referred to our medical oncology department for further treatment.
\end{abstract}

We shifted the treatment regimen to weekly cetuximab (loading dose $350 \mathrm{mg} / \mathrm{m}^{2}$, weekly maintenance $200 \mathrm{mg} / \mathrm{m}^{2}$ ) and weekly gemcitabine $\left(800 \mathrm{mg} / \mathrm{m}^{2}\right)$ plus cisplatin $\left(35 \mathrm{mg} / \mathrm{m}^{2}\right)$. The patient tolerated the treatment well; except for skin rashes and oral ulcers; there were no notable hematologic toxicities during treatment. The tumor showed regression after 4 months of treatment (fig. 1 and 2), and was evaluated as resectable. With the patient's permission, a left upper lobectomy (LUL) with superior segmentectomy via left thoracotomy was performed on 19 February 2008, and the pathological diagnosis was mucoepidermoid carcinoma stage T2N1. Further adjuvant chemotherapy with the same regimen was given for another 3 months. Presently in March 2009, the patient is still in complete remission with a good health status.

For NSCLC patients, resectability of the tumor is a critical point for long-term survival, and long-term survival is the therapeutic objective for initiating treatment. On the question of whether small molecular weight epidermal growth factor receptor (EGFR) inhibitors such as gefitinib and erlotinib, which are widely used for targeted treatment of unresectable NSCLC, can enhance tumor resectability or not, no published articles exist for systemic review. Furthermore,

Fig. 1. Computed tomography scan before (left) and post treatment (right). The circles indicate the tumor location. In the right image, the infiltration outside the circle was radiation pneumonitis.

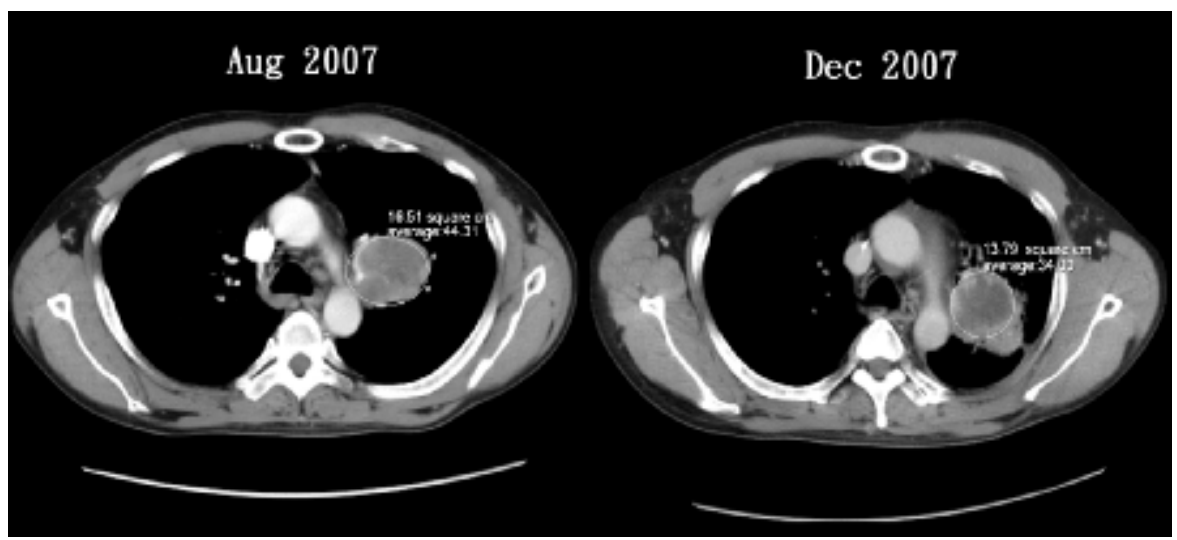

\section{KARGER}

Fax +497614520714

Information@Karger.de

www.karger.com
(C) 2009 S. Karger GmbH, Freiburg

Accessible online at:

www.karger.com/onk
Prof. Chih-Cheng Hsieh, MD

Taipei Veterans General Hospital

201 Shih-Pai Rd, Pei-Tou 112, Taipei, Taiwan

Tel. +886 22-8712121, Fax -7363051

cchsieh2@vghtpe.gov.tw 


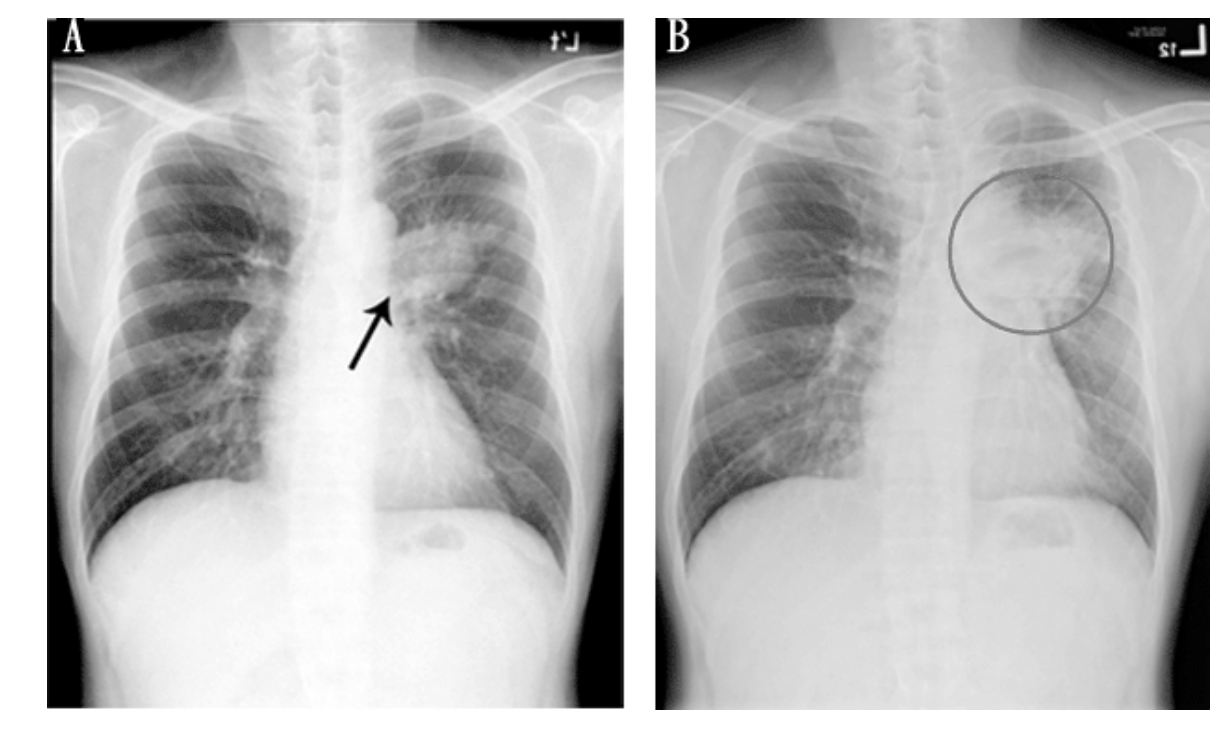

2. Chest X-rays $\mathbf{A}$ at start of treatment and $\mathbf{B}$ after 4 months of treatment just before surgery.

when given with conventional chemotherapy, reports of their use are also usually unsatisfactory [1]. One possible reason for the dissatisfaction with these EGFR inhibitors might be the poor performance status of the patients after several courses of treatment combined with high-dose conventional chemotherapy.

Several published reports indicate that combining chemotherapy with large molecular weight EGFR inhibitors such as cetuximab is an option for NSCLC patients [2-4]. Butts et al. [5] and Rosell et al. [6] revealed that when adding cetuximab to conventional chemotherapy, patients usually had an $8-10 \%$ higher response rate than those without cetuximab.

Since previous chemotherapeutic toxicities could have had a negative impact on the performance status of our patient, we used a typical weekly regimen with gemcitabine plus cisplatin combined with cetuximab, and this worked well on this patient [7]. We utilized lower doses of cetuximab based on concerns regarding the cost of the usual dose (loading $400 \mathrm{mg} / \mathrm{m}^{2}$, maintenance $250 \mathrm{mg} / \mathrm{m}^{2}$ ) and possibly higher dermatological toxicities in Asians. The lower dose was effective in this patient, with good tolerance. We suggest that appropriately applying targeted therapy with conventional chemotherapy could help achieve tumor resectability with less adverse effects.

\section{Conflict of Interest}

The authors declare that they have no conflict of interest.

\section{References}

1 Herbst RS, Giaccone G, Schiller JH, Natale RB, Miller V, Manegold C, Scagliotti G, Rosell R, Oliff I, Reeves JA, Wolf MK, Krebs AD, Averbuch SD, Ochs JS, Grous J, Fandi A, Johnson DH: Gefitinib in combination with paclitaxel and carboplatin in advanced non-small-cell lung cancer: a phase III trial--INTACT 2. J Clin Oncol 2004;22:785-794.

2 Hanna N, Lilenbaum R, Ansari R, Lynch T, Govindan R, Janne PA, Bonomi P: Phase II trial of cetuximab in patients with previously treated non-smallcell lung cancer. J Clin Oncol 2006;24:5253-5258.

>3 Belani CP, Schreeder MT, Steis RG, Guidice RA Marsland TA, Butler EH, Ramalingam SS: Cetuximab in combination with carboplatin and docetaxel for patients with metastatic or advanced-stage nonsmall cell lung cancer: a multicenter phase 2 study. Cancer 2008;113:2512-2517.
4 Borghaei H, Langer CJ, Millenson M, Ruth KJ, Litwin S, Tuttle H, Seldomridge JS, Rovito M, Mintzer D, Cohen R, Treat J: Phase II study of paclitaxel, carboplatin, and cetuximab as first line treatment, for patients with advanced non-small cell lung cancer (NSCLC): results of OPN-017. J Thorac Oncol 2008;3:1286-1292.

5 Butts CA, Bodkin D, Middleman EL, Englund CW, Ellison D, Alam Y, Kreisman H, Graze P, Maher J, Ross HJ, Ellis PM, Mcnulty W, Kaplan E, Pautret V, Weber MR, Shepherd FA: Randomized phase II study of gemcitabine plus cisplatin or carboplatin, with or without cetuximab, as first-line therapy for patients with advanced or metastatic non smallcell lung cancer. J Clin Oncol 2007;5:5777-5784.
6 Rosell R, Robinet G, Szczesna A, Ramlau R, Constenla M, Mennecier BC, Pfeifer W, O'Byrne KJ, Welte T, Kolb R, Pirker R, Chemaissani A, Perol M, Ranson MR, Ellis PA, Pilz K, Reck M: Randomized phase II study of cetuximab plus cisplatin/ vinorelbine compared with cisplatin/vinorelbine alone as first-line therapy in EGFR-expressing advanced non-small-cell lung cancer. Ann Oncol 2008;19:362-369.

7 Berardi R, Porfiri E, Scartozzi M, Lippe P, Silva RR, Nacciarriti D, Menichetti ET, Tummarello D, Carle F, Piga A, Cellerino R: Elderly patients with advanced non-small cell lung cancer. A pase II study with weekly cisplatin and gemcitabine. Oncology 2003;65:198-203. 